Revista Bioética

Print version ISSN 1983-8042 On-line version ISSN 1983-8034

Rev. Bioét. vol.26 no.1 Brasília Jan./Mar. 2018

Doi: 10.1590/1983-80422018261226

ATUALIZAÇÃO

\title{
The human right to liberty and Brazilian abortion practices
}

Milene Consenso Tonetto ${ }^{1}$

1. Programa de Pós-Graduação em Filosofia, Departamento de Filosofia, Universidade Federal de Santa Catarina (UFSC), Florianópolis/SC, Brasil.

\begin{abstract}
The aim of this paper is to justify women's right to abortion in the first trimester of pregnancy. Considering human rights as the protection of our normative agency or personhood, this paper will argue that human rights cannot be extended to human embryos and foetuses. In the first trimester of pregnancy, the moral status of the foetus is not sufficient to overcome the woman's right to the freedom to control her own body. There may be, however, moral considerations other than human rights that could restrict abortions after the first trimester of pregnancy. In order to protect human personhood and the most fundamentally accepted human rights - the rights to freedom, life, health and security of the body - countries like Brazil should decriminalize abortion in the first trimester of pregnancy and provide access to safe abortions through the public health care system.
\end{abstract}

Keywords: Human rights. Abortion. Reproductive rights. Freedom. Personhood.

\section{Resumo}

\section{O direito humano à liberdade e a prática abortiva brasileira}

O objetivo deste artigo é justificar o direito das mulheres ao aborto no primeiro trimestre de gestação. Se os direitos humanos são definidos como proteções da nossa agência normativa ou personalidade, então não poderão ser atribuídos aos embriões e fetos humanos. No primeiro trimestre de gestação, o status moral do feto não restringe o direito das mulheres à liberdade de controlar seu próprio corpo. No entanto, outras considerações morais podem impedir o aborto após os três meses iniciais de gestação, tais como: viabilidade, senciência e interesses. Finalmente, o artigo defende que o Brasil deve descriminalizar o aborto no primeiro trimestre de gestação e proporcionar acesso a abortos seguros via sistema público de saúde para proteger os direitos humanos amplamente aceitos, tais como: o direito à liberdade, à vida, à saúde e à segurança corporal. Palavras-chave: Direitos humanos. Aborto. Direitos reprodutivos. Liberdade. Pessoalidade.

\section{Resumen}

\section{El derecho humano a la libertad y la práctica abortiva brasileña}

El objetivo de este artículo es justificar el derecho de las mujeres a abortar en el primer trimestre de gestación. Si consideramos los Derechos Humanos como protección de nuestra agencia normativa o de nuestra personalidad, este artículo argumentará que los derechos humanos no pueden hacerse extensibles a los embriones y fetos humanos. En el primer trimestre de gestación, el estatus moral del feto no es suficiente para superar el derecho de las mujeres a la libertad de controlar sus propios cuerpos. Sin embargo, además de los derechos humanos pueden existir consideraciones morales que pueden impedir el aborto después del primer trimestre de gestación. Para proteger la personalidad humana y los derechos humanos más fundamentales aceptados - derecho a la libertad, a la vida, a la salud y a la seguridad del cuerpo - países como Brasil deberían despenalizar el aborto en el primer trimestre de gestación y brindar acceso a abortos seguros a través del sistema público de salud. Palabras clave: Derechos humanos. Aborto. Derechos reproductivos. Libertad. Personeidad.

Declara não haver conflito de interesse. 
The public discussion of abortion is sometimes framed as a conflict of rights between the foetus and the pregnant woman. On one hand, the antiabortion movement argues that the foetus has the right to life, and that the decision to undergo an abortion deprives it of the good of life. On the other, the pro-choice position claims that the woman has the right to have an abortion at any stage of her pregnancy. The legal prohibition of abortion appears to be against the woman's right to autonomy and control over her own body.

This paper will argue that neither approach is an appropriate way of dealing with abortion. Based on normative agency, I will argue that human rights cannot be extended to human foetuses. This does not mean, however, that foetuses have no moral value. Denying the rights of the foetus does not diminish its moral significance. Considering the moral status of foetuses at different stages of pregnancy means the woman's right to absolute autonomy in the control of her own body cannot be justified.

In the first trimester of pregnancy, questions about abortion must be settled by considering the right to liberty. The right to liberty implies freedom of action unless an overriding public interest exists. Thus, the choice to have an abortion cannot be plausibly justified only by women's right to autonomy in the control of their own bodies.

Firstly, the supposed right to control one's own body is an excessively broad and indeterminate concept. Secondly, discussing abortion only in terms of autonomy is to ignore a range of other relevant considerations. For instance, the justification of abortion rights cannot be indifferent to the status of the development of human life. We must then take into account the fact that later-stage foetuses have greater moral value than earlier stage foetuses as they are sentient and may have interests, be conscious, viable and able to live independently of their mothers.

This paper will therefore argue that only earlyterm abortion (up to the $12^{\text {th }}$ week of gestation) should be unrestricted. Up to this stage of pregnancy, women have the unlimited liberty to control their bodies and seek an abortion, and there is no public interest that overrides their right to freedom and choose what is best for them. After this gestational age, abortions should be reserved for restricted circumstances such as: risks to the woman's life, physical or mental health, foetal malformations that could undermine personhood and cases in which the pregnancy is the result of rape or incest.
The commitment to protect normative agency includes the rights to life, liberty and security of the body. These rights can justify the human right to safe abortion in early stages of pregnancy. It is reasonable, therefore, to also consider that abortion can be seen as an essential health care service. For this reason, countries should provide access to abortion through their public health care systems in the circumstances listed previously.

In Brazil, legal access to the termination of a pregnancy is highly restricted. According to the Brazilian Penal Code of 1940, abortion is a crime except to save the life of the woman or when pregnancy is the result of rape ${ }^{1}$. In 2012, the Supreme Court also authorized the "therapeutic anticipation of delivery" in cases of foetal anencephaly. A recently proposed bill, PL no. 5,069/2013 ${ }^{2}$, approved by the House Committee on Constitution and Justice, seeks to amend the Penal Code in order to restrict legal access to abortion.

The last section of this paper will analyse the proposed bill. My initial hypothesis is that it is an attempt to hinder access to legal abortion and to regulated care protected by Brazilian Law no. $12,845 / 2013^{3}$, which provides for the mandatory and comprehensive care of people in situations of sexual violence. Based upon normative agency, this paper will show that the bill contradicts the most fundamental and generally accepted human rights to freedom, life, health and security of the body.

\section{Women's right to autonomy and the attribution of rights to embryos and foetuses}

In recent decades, grounding human rights in normative agency or personhood has gained strong advocates. In his book "On human rights", James Griffin argues that human rights are protections of our human ability to form and pursue conceptions of a worthwhile life. He refers to this capacity as normative agency or personhood. The concept of personhood can be better understood by analysing the notion of agency. According to Griffin, this concept can be divided into three clear components:

To be an agent, in the fullest sense of which we are capable, one must (first) choose one's own path through life - that is, not be dominated or controlled by someone or something else (call it "autonomy"). And (second) one's choice must be real; one must have at least a certain minimum education and information. And having chosen, one must then 
be able to act; that is, one must have at least the minimum provision of resources and capabilities that it takes (call all of this "minimum provision"). And none of this is any good if someone then blocks one; so (third) others must also not forcibly stop one from pursuing what one sees as a worthwhile life (call this "liberty") ${ }^{4}$.

Because we attach a high value to our individual personhood, we see its domain of exercise as something valuable to be protected. Grounding human rights in personhood imposes obvious constraints on their content: they are rights not to anything that promotes human good or flourishing, but merely to what is needed for human status. They are protections of that somewhat austere state, a characteristically human life, not of a good or happy or perfected or flourishing human life ${ }^{5}$.

The element of austerity and the reference to a minimum must not be lost in determining the content of human rights. What is necessary for our status as agents includes autonomy, liberty and some sort of minimum material provision, which is more than just subsistence. And what is needed to function as a normative agent will be air, food, water, shelter, rest, health, companionship, education, and so on.

To determine a human right as sufficient to guide our behaviour, we need another grounding, that is, practicalities. Practicalities are not tied to particular times or places: They are universal, as any existence condition for rights that one has simply in virtue of being human must be. Practicalities will be empirical information about (...) human nature and human societies, prominently about the limits of human understanding and motivation ${ }^{6}$. Thus, according to Griffin, to make the content of rights sufficiently determinate we need some considerations, such as how human beings and their societies work. This degree of determinateness must be among the existence conditions for human rights.

Griffin argues that another way to improve the justification of human rights is to stipulate that only normative agents bear human rights. Here, we need to consider the problem of setting the boundaries of when a human being is a normative agent. Griffin's position is that:

Children become agents only with time, and one requires a good run of adult years to form mature aims and to have time to realize some of the most major ones. And many people in old age naturally lose some of the powers of agency, and often the major achievements in their lives are already behind them. This hardly means that there is no longer a moral case for caring for the elderly, but agency may play a smaller part in it? ${ }^{7}$.

The vulnerability of infants, children, elderly, severely mentally ill and people in a coma imposes a substantial obligation on us. In the natural development of a child, the capacity for autonomy and liberty appears in stages. Respect for the child's personhood should therefore increase in parallel stages. According to Griffin many children, as opposed to infants, are capable of normative agency ${ }^{8}$. That is to say, his scepticism about the rights of the foetus does not extend to children's rights: children are capable of some degree of agency much younger than that. The autonomy of children of only a few years has sometimes to be respected, and they rightly think that their dignity is affronted if it is not ${ }^{9}$.

For this reason, children must be seen as acquiring rights in stages, just as they acquire agency. In Griffin's account of personhood, then, human rights cannot be extended to embryos and foetuses. However, denying that foetuses have rights need not diminish their moral consideration. As we argue, we can respect the lives of foetuses by considering other moral values.

There are groups which invoke the right to life to justify banning abortion. Anti-abortion positions consider that foetuses have the right to life. They argue that since it is wrong to kill innocent human beings, and as foetuses are innocent human beings, it is therefore wrong to kill foetuses. In the personhood account, however, agency is the source of the values protected by rights. These protections cannot be extended to beings who are not agents. Thus, foetuses do not yet have any human rights to be infringed. In this sense, the right to life does not imply a prohibition of abortion: embryos and foetuses do not have human rights, though there may be moral considerations other than human rights that serve to prohibit abortions ${ }^{10}$.

Neither does the human right to life imply the prohibition of contraception. The preconception forms of life that can produce a human person do not have human rights. Foetuses do not yet have the capacity to act as normative agents. As was argued, many elderly and comatose patients lose the power to act as normative agents. This does not mean that we do not have a moral duty to care for foetuses, infants, comatose patients and elderly people. If possible, physicians and carers have the duty to give their power of agency 
back to the elderly and the comatose patients. And parents have the duty to promote the full development of an infant.

Even if infants and healthy late foetuses do not have rights, parents cannot deliberately kill them as this would be murder. However, there are lives in which the bad irreversibly overwhelms the good. Foetuses with serious physical problems such as anencephaly will never be normative agents, and there is nothing in the personhood account that implies that life must be extended as long as possible or that health must be as rude as possible ${ }^{11}$.

Which moral considerations should we take into account to avoid abortion? Griffin asserts that a human life has an intrinsic value as well as a value for the person living it. The dignity of having a rational nature includes exercising it in making rational judgements, and one cannot respect a rational nature and therefore its exercise without respecting those judgements, which may well concern what is good for persons ${ }^{10}$. According to this author, the human right to life protects the intrinsic value of human life by protecting our personhood in a general sense, but there is nothing in the intrinsic value that makes it incommensurable with the other two values, the values for oneself and for others, nor anything that makes it resistant to frequently being outweighed by the value of the life for the person who lives it ${ }^{10}$.

Early foetuses and zygotes are not agents. An infant with extreme spina bifida who will die within a few months of birth or an anencephalic baby will never be an agent. Their intrinsic value can be outweighed by the value of a normative agent. In some cases, the intrinsic value argument cannot restrict the decision regarding abortion.

Restrictions on abortion can also arise from religious concerns. Specific human rights can be justified from the perspectives of autonomy, liberty and minimum provision. Under liberty, for example, fall several well-known freedoms, such as freedom of expression, of religion, of assembly ${ }^{12}$. Thus, people are free to hold religious beliefs that prevent them performing abortion.

However, if we consider the background of religious differences, it appears that the disagreement over abortion arises from different metaphysical beliefs. A secular state, then, cannot criminalize abortion based on concerns of faith. In the next section, we will see that women's right to abortion cannot be derived from the absolute right to control their own bodies, but from liberty, which can only be restricted by public interest.
The human right to liberty and the permissibility of abortion

In the account of personhood, the human right to liberty is derived from the value of being able to pursue our own conception of a worthwhile life: Liberty guarantees not the realization of one's conception of a worthwhile life, but only its pursuit ${ }^{13}$. The right to liberty can be restricted in many ways, not merely in the form of active intervention. It can be physically prevented by another person, or by a law that penalizes, or by the threats of an absolute ruler. Constraint and compulsion are enemies of liberty, although the forms they take are not always easy to recognize. A state, church or family can compel someone to live in a way that is neither wanted nor desired.

Liberty is not fully satisfied simply by noninterference in the way of life that one has chosen. The pursuit of a plausible conception of a worthwhile life requires that society applies some means or positive obligations to guarantee its provision. For instance, education, basic health, minimum material provision, help to overcome lack of key capacities, a fairly rich array of options, and so on. To what level of all-purpose means? To the level needed to live as a normative agent ${ }^{14}$.

What is needed to function as a normative agent are education, air, food, water, shelter, health, and other such elements. As can be seen, liberty has a positive and a negative side. One can respect liberty by simply not interfering in the goals of others. However, when we consider the chances of acquiring a worthwhile life, liberty may include positive duties.

According to Griffin, a general right to liberty is a right to do various things: to pursue the life one values, and perhaps also to use contraceptives, to have an abortion, and to commit suicide ${ }^{15}$. If we consider the case of suicide we can conclude that there is a public interest in restricting the liberty of a healthy person who tries to commit suicide. For instance, the suicide of a mother can interfere with her children's moral right to be cared for. It therefore seems plausible to think that there is a public interest to prevent suicide when it interferes with one's rights.

Consider now the case of abortion. A foetus at a late stage of gestation can be morally considered a being with sentience and interests ${ }^{16}$. The act of deliberately killing a being with such interests or the viability to live outside the mother's womb can be considered harm. 
One interpretation of the right to liberty argues that one's body is a private space, within which one is sovereign to determine what can happen. Judith Thomson ${ }^{17}$ argues that we can determine what happens in and to one's body. In this way, she is justifying a woman's right to abortion. In Thomson's famous example, a woman kidnapped by the Society of Music Lovers is hooked up to a famous violinist in hospital, who will die if she withdraws the support her body provides. While it might be virtuous to remain hooked up to the violinist, Thomson argues that morality does not require it:

Is it morally incumbent on you to accede to this situation? No doubt it would be very nice of you if you did, a great kindness. But do you have to accede to it? What if it were not nine months, but nine years? Or longer still? What if the director of the hospital says, "Tough luck, I agree, but you've now got to stay in bed, with the violinist plugged into you, for the rest of your life. Because remember this. All persons have a right to life, and violinists are persons. Granted you have a right to decide what happens in and to your body, but a person's right to life outweighs your right to decide what happens in and to your body. So you cannot ever be unplugged from him". I imagine you would regard this as outrageous, which suggests that something really is wrong with that plausible-sounding argument I mentioned a moment ago ${ }^{18}$.

Thomson's argument stresses bodily integrity and self-ownership, and claims that if we accept these premises we can only allow foetuses to use women's bodies with the women's consent. She then maintains that having a right to life does not guarantee either having the right to be given the use of or to be allowed the continued use of another's body. Therefore, the right to life does not serve the opponents of abortion.

According to Griffin, women's right to abortion cannot be justified by the argument of controlling one's own body, nor by the conception of private space or private life. Abortion does not always take place within private space (the home, the marital bedroom) but often in clinics or hospitals with doctors and nurses in attendance. Nor is an abortion a matter of a personal relationship; it is in part a matter of a professional relationship ${ }^{19}$. The permissibility of abortion must be discussed independently from the supposed right to privacy and to control one's own body. We do not have the right to control what happens in and to our bodies as it is too broad and indeterminate a right:
Would it protect a woman's taking drugs likely seriously to deform her foetus, or having as many children as she wants? Would it make mandatory drugs tests for airline pilots an infringement of their rights? Would it give us a human right to sell our body parts? I suspect that there is nothing to this supposed right except what is already included in the right to liberty or in the right to security of person ${ }^{20}$.

The human right to liberty does not consist of doing anything you want to. As we have seen, there are some public concerns that can justifiably restrict our liberty. The supposed right to control what happens in and to one's body can allow some actions that are not consistent with the widely accepted right to the security of a person. For instance, many governments prohibit us from selling our body parts. It is plausible to think that this prohibition does not infringe our human rights. For this reason, it is more acceptable to think that we have the right to obtain an abortion through the justification of the right to the liberty to pursue a worthwhile conception of life.

Liberty is an essential aspect of our agency that requires letting people be free to pursue any plausible conception of life. In this way, the right to liberty can justify a voluntary choice to terminate a pregnancy in specific cases. Since a foetus is not yet capable of agency, it is not entitled to the right to be disrespected. Yet even if abortion does not violate the rights of foetuses, it may still be immoral for other reasons. Different values can be taken into consideration when discussing if foetuses may have moral value, such as sentience and interest in not being harmed, intrinsic value, and the viability to live outside the mother's womb.

There are different stages and degrees to these types of value. It appears consensual, for example, that in the second and third trimesters, foetuses have greater moral value than in the first trimester. Up to twelve weeks, the central nervous system of the foetus has not yet formed and there is no possibility of it living independently from the woman. As Margaret Little points out:

In the first trimester, the intrinsic moral status of early human life is modest, the burden of continuing deep, and the fetus has no trajectory independent of the woman's gestational assistance. The profound and on-going nature of the assistance implicate rights of bodily dominion; further, given that the life is not yet a child, abortion rights at this stage have a leg in the rights of reproductive decisional privacy ${ }^{21}$. 
In the first trimester, the moral status of foetuses is not sufficient to outweigh women's right to freedom. Consequently, abortion should be unrestricted and decriminalized in order to respect the woman's right to autonomy. After this phase, different justifications apply to the termination of pregnancy. Abortions in the second and third trimesters are more expensive, risky, and emotionally difficult. After the first trimester, then, abortions should be reserved for restricted circumstances which include risks to the woman's life, physical or mental health, foetal malformation and cases in which pregnancy was the result of rape or incest.

In early pregnancies, the moral worth of foetuses should be respected in ways different from restricting women's freedom. Even in cases in which the pregnancy does not put a mother's life at risk, denying abortion will violate women's liberty. There are cases in which the mother is neither physically nor mentally at risk and the baby is in good health. A pregnant teenager can feel very frightened, particularly if her pregnancy was not planned. In cases such as these, pregnancy can damage her plans for her life, education and career and her financial prospects. In other words, it can restrict her pursuit of a worthwhile life. It is important to point out that abortion cannot be used as a form of birth control. Contraception is always preferable to abortion in terms of public health and morality.

In the second and third trimester, abortions can be justified when the pregnancy is the result of rape or incest. Pregnancies resulting from non-consensual sexual relations violate women's right to security and bodily integrity. Consider now cases of late term pregnancy where there are risks of severe foetal abnormality, such as anencephaly or spina bifida. Significant disabilities are usually detected only after the first trimester. Serious physical deformity, intellectual disabilities and genetic problems can result in an unacceptable quality of life.

These abnormalities undermine the personhood of the foetus and its capacity for agency. If a woman voluntarily wishes to end her pregnancy in such cases, and a doctor is prepared to carry out the procedure, the law must not interfere. There are, however, some mildly troubling reasons for wishing to abort in the second and third trimesters, such as the desire to have a baby of a different sex, usually male rather than female, or minor disabilities which if treated early can be corrected.

Some disability rights activists are concerned about the abortion of disabled foetuses as it is a form of discrimination against disabled people. In the same way, feminists point out that sex-selective abortions constitute a type of sexism. Personhood accounts of human rights defend liberal principles that would never require a woman to abort against her will. A woman would feel more encouraged to have a disabled baby if she knew her country's public health system would provide measures to support her and improve the quality of life of the child. Thus, in a situation where the morality of abortion is complex and sensitive, women and couples should be free to decide whether or not to carry on with pregnancies.

To have access to a safe abortion seems indispensable to ensure that the human rights to life, freedom, autonomy and security of the body are secured. There are cases where pregnancy puts the mother's life at risk and consequently can undermine her capacity for agency. For instance, conditions like preeclampsia, which causes high blood pressure, can threaten the lives of pregnant women and consequently undermine their capacity to agency. Consider also a pregnant woman whose baby has anencephaly and will probably not survive to term or will die in the first hours or days after birth, which can be devastating to the mental health of the pregnant woman. In such cases it seems plausible to justify the right to abortion for the sake of the mother's health, including her mental health.

In the personhood account, we have a right to life as it is a necessary condition of normative agency. There is a positive aspect of the human right to life that cannot be dismissed. For instance, we have a right to the health support necessary to our functioning as normative agents. The right to health care is a right to welfare provision that can include not only medicines and treatments, but also advice about contraceptive methods and family planning. In many cases, abortion can be considered an essential form of health care to protect women's physical and mental health. Governments and public health systems should provide such care in an easily accessible and well-publicized manner. Other services should be included, such as reproductive education, pre- and post-abortion advice, and information about the possibility of giving the child up for adoption.

\section{Abortive practice and its decriminalization in Brazil}

According to the World Health Organization (WHO), legislation that restrict abortion does 
not reduce its practice. On the contrary, it forces women to have unsafe abortions in clandestine clinics frequently performed by individuals or groups lacking qualifications and skills to perform them. As a result, laws that criminalise abortion do not protect women: where abortion laws are the least restrictive there is no or very little evidence of unsafe abortion, while legal restrictions increase the percentage of unlawful and unsafe procedures ${ }^{22}$.

Laws criminalizing abortion can violate women's rights to liberty, life and security of person. Almost all deaths and morbidity from unsafe abortion occur in countries where abortion is severely restricted in law and in practice (...) Where there are few restrictions on access to safe abortion, deaths and illness are dramatically reduced ${ }^{23}$. For these reasons, WHO recommends that safe and legal abortions are available to all women.

The proposal of WHO makes sense. It is hardly coincidental that Brazil has some of the strictest abortion laws in the world and also some of the highest abortion rates. The 1940 Brazilian Penal Code says that a physician may perform an abortion only when the life of the mother is at risk and when pregnancy is the result of rape. In cases of rape, the pregnant woman must consent to the abortion or, if she is incompetent, her legal representative must provide such consent. In 2012, the Supreme Court also authorized the "therapeutic anticipation of delivery" in cases of foetal anencephaly. Brazilian women who are suspected of terminating pregnancies, and those who carry out or assist in abortions that do not fall under these categories face prosecution if reported.

Legislation restricting abortion does not decrease its practice in Brazil. According to Diniz and Medeiros ${ }^{24}$, who presented the first results of the National Abortion Survey in Brazil, one in five Brazilian women has had an abortion by the end of their reproductive health. Abortion was found to be more common among less educated people. The use of medical drugs to induce abortion occurred in half of the abortions, and post abortion hospitalization was observed among approximately half of the women who aborted.

A recently proposed legislation, bill PL no. $5,069 / 2013$, attempts to restrict legal access to abortion in Brazil. The House Committee on Constitution and Justice (CCJ) approved the bill on October 21, 2015. It will now go to a vote and, if approved by lawmakers, will amend the Brazilian Penal Code to criminalize inducing or encouraging a pregnant woman to have an abortion, including providing assistance to do so, except in cases of legal abortion.
The current Brazilian Penal Code (art. 128) states that only the woman herself and the doctor performing the abortion procedure can be held accountable. The new bill, however, would extend criminal proceedings to health professionals, such as physicians, pharmacists and nurses, who assist or inform women about abortive procedures, with a possible prison sentence of up to ten years.

Bill PL no. 5,069/2013 also changes the content of Law no. 12,845/2013, establishing rules for the care of women who are victims of sexual violence. It excludes the definition in the existing law (art. 2) that establishes sexual violence to mean all forms of non-consensual sexual activity, even when there is no physical evidence of violence. Bill $\mathrm{PL}$ no. 5,069 reintroduces the requirement that a raped woman must file a police report and have a medical examination if she is to be able to request an abortion.

The technical standard from the Brazilian Ministry of Health (2012) determines that there is a presumption of veracity in the word of a woman ${ }^{25}$, meaning that the word of a victim of sexual violence is sufficient to obtain health care assistance. The new bill, therefore, may exclude many cases where rape is committed without physical violence, either by coercion, threat or when the victim is unconscious.

Pro-choice activists say rape victims will lose all the rights granted by Law no. 12,845/2013 (art. 3 ): the right to the morning-after pill, the prevention of pregnancy and of sexually transmitted diseases, plus the right to have a follow-up HIV test, therapy and further information about their medical rights. This also implies that a physician who provides an abortion without material evidence will be committing a crime. Bill PL no. 5,069 could change the existing legal terminology of allowing "pregnancy prevention" for women who become pregnant due to rape to allowing only a non-abortive procedure or medication that may provide early and efficient prevention of pregnancy resulting from rape.

There is a risk this would mean that the morningafter pill could also be considered abortive and, therefore, become restricted. As we can see, the proposed bill foresees substantial changes to the Brazilian Penal Code and Law no. 12,845 that could undermine acquired rights to procedures to prevent pregnancy, to the morningafter pill and to basic health care.

I have argued in this paper that agency and personhood can justify the human right to safe abortion. The human right to life, liberty and bodily integrity are indispensable ingredients of normative 
agency or human personhood. In the first trimester of gestation, the human right to liberty justifies a woman's decision to have an abortion for any reason. There are no public interests that override women's right to liberty and to choose what is best for them.

The Brazilian Penal Code should therefore decriminalize abortion in the first trimester of gestation. After this stage, abortion must be decriminalized when the pregnancy puts the woman's life or physical or mental health at risk, when foetuses have malformations that can undermine their personhood and when the pregnancy is the result of rape or incest. In these cases, denying women's right to access to a safe abortion will be contrary to the most fundamental human rights, such as the human right to life, to physical and mental health and to bodily integrity. Consequently, the proposed bill PL no. 5,069/2013 must not be approved.

The bill ignores the reality of women and girls in Brazil. According to Debora Diniz, the bill will punish an alarming number of adolescents: over 36 percent of legal abortions in the country are for victims of sexual violence who are under 19 years of age ${ }^{26}$. The bill represents a throwback as it goes against Brazilian Law no. 12,845/2013, which ensures health care for people in situations of sexual violence, including all forms of non-consensual sexual activity. It is evident that the bill attempts to hinder access to legalized abortion and to regulated care. In closing, the Brazilian Penal Code should decriminalize abortion in the first trimester of gestation and in restricted cases in the second and third trimesters.

\section{Final considerations}

As I have argued, a commitment to abortion rights requires neither asserting that foetuses have no moral value nor that women have absolute autonomy to control their bodies in the later stages of pregnancy. Human rights cannot be extended to foetuses as they do not have elements of personhood such as autonomy, liberty and minimum provision. They can, however, have other moral considerations, such as intrinsic value, sentience, viability to live outside the mother's womb and interests. These values possess different degrees according to the stage of development of the human foetus. Up to twelve weeks, the central nervous system of the foetus has not yet formed and there is no possibility of it living independently from its mother.

Early in pregnancy, the moral status of the foetus is not sufficient to outweigh the right of the woman to freedom and the autonomy to control their own bodies. Thus, abortion should be unrestricted and decriminalized to respect the woman's right to freedom, autonomy and privacy. After this, the termination of pregnancy should be restricted to the following circumstances: to save the mother's life, to preserve the mother's physical and mental health, and to preserve bodily integrity in cases of rape and incest.

In the personhood account, we have a right to life because life is a necessary condition of normative agency. The protection of the life of a normative agent has a positive side that cannot be dismissed. For instance, living as a normative agent requires a certain level of health. Therefore, we have a right to the health support necessary for our functioning as normative agents. In many cases, abortion can be considered essential health care for the protection of women's lives and physical and mental health.

Governments should provide abortion in an easily accessible and well-publicized manner, and other services such as reproductive education, family planning, pre- and post-abortion advice and information about the possibility of giving the child up for adoption should also be ensured. All people have rights to liberty, life, security and integrity. Thus, the right to obtain an abortion cannot be denied in cases where the pregnancy puts the mother's life, liberty, security and body integrity at risk. From the conception of normative agency, it is therefore possible to justify the right of women to access to a safe abortion.

This article is the result of my postdoctoral research carried out at the University of Oxford. I would like to thank the Brazilian Federal Agency Coordenação de Pessoal de Nivel Superior (Capes) for supporting my research at the Oxford Uehiro Centre for Practical Ethics.

\section{Referências}

1. Brasil. Decreto Lei no 2.848, de 7 de dezembro de 1940. Código Penal [Internet]. Brasília; 1940 [acesso 31 maio 2016]. Disponível: http://bit.ly/1Hvh4Vo

2. Brasil. Câmara dos Deputados. Projeto de Lei no 5.069, de 2013. Acrescenta o art. 127A ao Decreto-Lei no 2.848, de 7 de dezembro de 1940 - Código Penal [Internet]. Câmara dos Deputados. Brasília; 27 fev 2013 [acesso 31 maio 2016]. Disponível: http://bit.ly/2mMIOKQ 
3. Brasil. Lei no 12.845 , de 1으 de agosto de 2013. Dispõe sobre o atendimento obrigatório e integral de pessoas em situação de violência sexual [Internet]. Diário Oficial da União. Brasília; 2 ago 2013 [acesso 31 maio 2016]. Disponível: http://bit.ly/1x5gFB9

4. Griffin J. On human rights. Oxford: Oxford University Press; 2008. p. 33.

5. Griffin J. Op. cit. p. 34.

6. Griffin J. Op. cit. p. 38.

7. Griffin J. Op. cit. p. 101.

8. Griffin J. Op. cit. p. 94.

9. Griffin J. Op. cit. p. 95.

10. Griffin J. Op. cit. p. 220.

11. Griffin J. Op. cit. p. 100.

12. Griffin J. Op. cit. p. 159.

13. Griffin J. Op. cit. p. 160.

14. Griffin J. Op. cit. p. 162.

15. Griffin J. Op. cit. p. 230.

16. Jaggar AM. Abortion rights and gender justice. In: Tooley M, Wolf-Devine C, Devine PE, Jaggar AM. Abortion: three perspectives. New York: Oxford University Press; 2009. p. 127-71.

17. Thomson JJ. A defense of abortion. Philosophy \& Public Affairs. 1971;1(1):47-66.

18. Thomson JJ. Op. cit. p. 49.

19. Griffin J. Op. cit. p. 232.

20. Griffin J. Op. cit. p. 239.

21. Little M. Abortion \& the margins of personhood. Rutgers Law Journal. 2008;39:344.

22. World Health Organization. Unsafe abortion: global and regional estimates of the incidence of unsafe abortion and associated mortality in 2008 [Internet]. 6 $^{\text {th }}$ ed. Geneva: WHO; 2011 [acesso 31 maio 2016]. p. 6. Disponível: http://bit.ly/1MiJosp

23. World Health Organization. Safe abortion: technical and policy guidance for health systems [Internet]. Geneva: WHO; 2012 [acesso 31 maio 2016]. p. 87. Disponível: http://bit.ly/RNZAwJ

24. Diniz D, Medeiros M. Aborto no Brasil: uma pesquisa domiciliar com técnica de urna [Internet]. Ciênc Saúde Coletiva. 2010 [acesso 31 maio 2016];15(1 Suppl):959-66. Disponível: http://bit. Iy/2DeGXdL

25. Brasil. Ministério da Saúde, Secretaria de Atenção à Saúde, Departamento de Ações Programáticas Estratégicas. Prevenção e tratamento dos agravos resultantes da violência sexual contra mulheres e adolescentes: norma técnica [Internet]. 3ạ ed. Brasília: Ministério da Saúde; 2012 [acesso 31 maio 2016]. p. 69. (Direitos Sexuais e Direitos Reprodutivos, 6). Disponível: http://bit.ly/1vztCad

26. Diniz D. Eduardo Cunha, quem é a mulher mentirosa? Justificando [Internet]. São Paulo; 2015 [acesso 31 maio 2016]. Disponível:http://bit.ly/2EUQmHT

\section{Correspondência}

Universidade Federal de Santa Catarina. Departamento de Filosofia. Rua Eng. Agrônomo Andrei Cristian Ferreira, s/n, Trindade. CEP 88040-900. Florianópolis/SC, Brasil.

Milene Consenso Tonetto - Doutora - milene.consenso.tonetto@ufsc.br

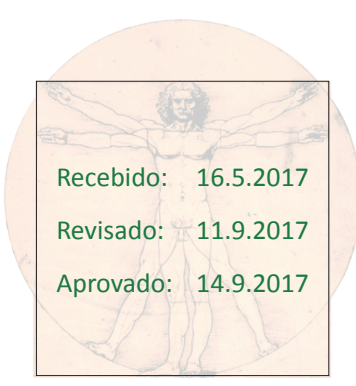

